\title{
THEON OF ALEXANDRIA'S OBSERVATION OF THE SOLAR ECLIPSE OF A.D. 364 JUNE 16
}

\author{
ALEXANDER JONES, \\ Institute for the Study of the Ancient World, New York University
}

In a recent review, Raymond Mercier raises in passing an issue that deserves to be highlighted, namely the difficulties created for modern historians by the lack of an adequate complete edition and translation of one of the principal documents of later Greek astronomy, Theon of Alexandria's commentary on Ptolemy's Almagest. ${ }^{1}$ For the first four books we have the exemplary critical edition (lightly annotated but regrettably without translation) by Adolphe Rome, ${ }^{2}$ but Rome did not live to finish the project, and we may have to wait a long time for someone with the requisite competence and stamina to take up where he left off. In the meantime the only printed text for a large part of the commentary is the cumbersome 1538 Basel edition, ${ }^{3}$ which was based on a single, not particularly authoritative manuscript (Nürnberg Stadtbibliothek Cent. V, App. 8, formerly owned by Regiomontanus), and again lacks a translation so that it is effectively inaccessible to many modern researchers. The present note makes an extremely modest and provisional contribution to rectifying this situation by offering a more reliable text and translation of a mere sentence, comprising Theon's observation report of the solar eclipse of A.D. 364 June $16 .{ }^{4}$

I give the passage as it appears on f. 242r of the ninth-century Laur. plut. 28.18, which is by a wide margin the oldest, and in Rome's judgement the most accurate, manuscript of the first six books of Theon's commentary: ${ }^{5}$

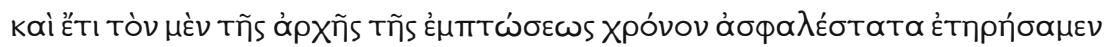

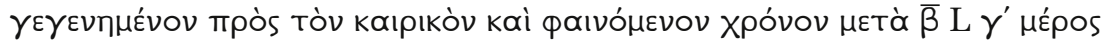

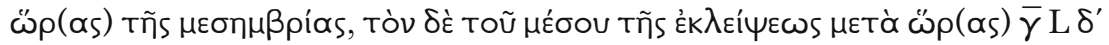

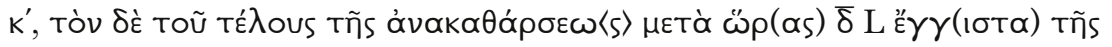

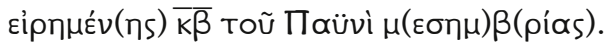

And moreover we observed most securely the time of the beginning of the immersion, with respect to seasonal and apparent time, $2 \frac{1}{2} \frac{1}{3}$ hours after noon, and the (time) of the middle of the eclipse $3 \frac{1}{2} \frac{1}{4} \frac{1}{20}$ hours after (noon), and the (time) of the end of the clearing approximately $4 \frac{1}{2}$ hours after noon of the aforesaid $22 \mathrm{nd}$ of Payni.

The 1538 edition has a couple of variants immaterial for the meaning, and one significant one where instead of $\mu$ épos ("fraction", qualifying the preceding numerals)

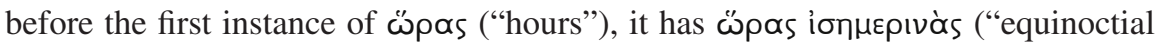
hours"). In an article on Theon's calculation of the circumstances of the eclipse Rome writes about the observation report at some length, pointing out that the unpublished 
version in Laur. plut. 28.18 was undoubtedly correct in not having the word 'equinoctial', so that the observed times are expressed in seasonal hours after noon, resolving a conflict that Fotheringham had found between modern theory and Theon's times on the supposition that they were in equinoctial hours. ${ }^{6}$ (Times in seasonal hours were more commonly counted from sunrise or sunset.) It is worth noting that the reported time of mid-eclipse is not simply the moment halfway between the beginning and end of obscuration, so Theon appears to have attempted to determine the point when the obscuration was at its maximum. ${ }^{7}$

\section{REFERENCES}

1. JHA, xlii (2011), 405-8.

2. A. Rome, Commentaires de Pappus et de Théon d'Alexandrie sur l'Almageste, II and III (Studi e Testi 72 and 106; Vatican, 1936-43).

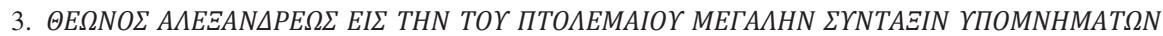
BIBA. IA. Theonis Alexandrini in Claudii Ptolemaei Magnam Constructionem Commentariorum Libri XI. Basileae Apud Ioannem Vualderum [1538]. A digitization is available at http://www. mpiwg-berlin.mpg.de/en/resources/library.html.

4. Reviewing J. M. Steele's contribution to Ptolemy in perspective, Mercier writes that the paper is "spoiled by Steele's acceptance of Theon's 'observation' in Alexandria of the solar eclipse of 364 June 16, but here he simply follows a habit that goes back to Fotheringham", and he goes on to state categorically but mistakenly that Theon "never reported his observations as such", and that this is "quite clear to any one who troubles to read the whole Greek text of Theon's commentary on Book 6 of the Almagest". Fotheringham certainly did read it, since he provides a page reference to the Basel edition (p. 322) and loosely translates the crucial passage, which is close to the beginning of Theon's discussion of the eclipse; see J. K. Fotheringham, "A solution of ancient eclipses of the Sun", Monthly notices of the Royal Astronomical Society, 1xxxi (1920), 104-26, p. 114. Theon's observation report is omitted in another version of the calculation of the eclipse, existing both as an independent text and as an insertion in Theon's Little commentary on the Handy Tables, edited in A. Tihon, "Le calcul de l'éclipse du Soleil du 16 juin 364 p.C. et le 'Petit Commentaire' de Théon”, Bulletin de l'Institut Historique Belge de Rome, xlvi-xlvii (1976-77), 35-79.

5. A digitization of the manuscript is available at http://teca.bmlonline.it/TecaRicerca/.

6. A. Rome, "The calculation of an eclipse of the Sun according to Theon of Alexandria", in Proceedings of the International Congress of Mathematicians, Cambridge, Mass., 1950 (Providence, 1952), i, 209-19. Of course Fotheringham could not have seen the text in Laur. plut. 28.18. He perhaps ought to have been troubled by the conflicting phrase about "seasonal and apparent time", but he chooses to translate this inaccurately as "civil and apparent time", thus concealing the clue.

7. It is not clear to me whether Theon intends to indicate that the time of the beginning was observed more precisely than the time of the end, as Rome, "Calculation" (ref. 6) asserts; the adverb ("approximately", or literally "most nearly") does not signify roughness but usually that a stated number is as close to the accurate value as the chosen precision allows. 